\title{
Morphological and physsicochemical characterization of biochar produced by gasification of selected forestry species
}

\author{
Caracterización morfológica y fisico-química de biocarbones producidos \\ por la gasificación de especies forestales seleccionadas
}

\author{
Caracterização morfológica e físico-química de biocarvões produzidos \\ pela gasificação de espécies florestais selecionadas
}

\begin{abstract}
In this study, biochar samples acquired as by-product by downdraft gasification at $700{ }^{\circ} \mathrm{C}$ from Eucalyptus grandis (BC-EG), Acacia magnium (BC-AM) and Gmelina arborea (BC-GA) were characterized. The morphological characteristics and physicochemical properties of biochar were studied using nitrogen physisorption by the Brunauer-Emmet-Teller (BET) method, Scanning Electron Microscopy (SEM), X-ray Energy Dispersive Spectrometry (EDX) and Fourier Transform Infrared Spectroscopy (FTIR). The surface area (SA) of the materials was in the 2.0-50.0 $\mathrm{m}^{2} / \mathrm{g}$ range, with the biochar obtained from BC-EG showing the highest $\mathrm{SA}\left(50.0 \mathrm{~m}^{2} / \mathrm{g}\right)$, while the biochar derived from BC-GA showed the lowest SA $\left(2.0 \mathrm{~m}^{2} / \mathrm{g}\right)$. In addition, all samples can be classified as mesoporous materials because their pore sizes were between 2 and $50 \mathrm{~nm}$. This indicates that these materials can be used in absorption processes; however, the biochar obtained from BC-AM is expected to be the most suitable for absorption applications. FTIR biochar spectra did not exhibit characteristic peaks for cellulose or hemicellulose in any sample due to decomposition of these compounds at the gasification temperature. Moreover, according to SEM/EDX analyzes, all the samples presented well-defined pore structure and contained minerals as $\mathrm{Na}, \mathrm{K}$ and $\mathrm{Ca}$, suggesting that the biochar could also be useful for soil amendment applications.
\end{abstract}

Keywords: Acacia; Biomass charcoal; Eucalyptus; Forestry products; Forestry species; Gmelina; Physicochemical property.

\section{Resumen}

En este estudio se caracterizaron muestras de biocarbones obtenidos como subproducto del proceso de gasificación, en lecho fijo a $700{ }^{\circ} \mathrm{C}$, de las especies Eucalyptus grandis (BC-EG), Acacia magnium (BC-AM) y Gmelina arborea (BC-GA). Sus características morfológicas y propiedades fisicoquímicas se evaluaron usando

* M. Sc. Instituto de la Ciencia y la Tecnología Alimentaria INTAL (Medellín-Antioquia, Colombia). produccioncientifica@intal.org.

** Ph. D. Politécnico Colombiano Jaime Isaza Cadavid (Medellín-Antioquia, Colombia). anardila@elpoli.edu.co.

*** Ph.D. Universidad de Antioquia (Medellín-Antioquia, Colombia). rolando.barrera@udea.edu.co. ORCID: 0000-0002-8718-9242. 
fisisorción de nitrógeno por el método de Brunauer-Emmet-Teller (BET), espectroscopia de dispersión de energía de rayos X (EDS) y espectroscopia infrarroja con Transformada de Fourier (FTIR). Los biocarbones analizados presentaron áreas superficiales en el rango de $2.0-50.0 \mathrm{~m}^{2} / \mathrm{g}$; el biocarbón originado de la especie BC-EG presentó la mayor área superficial $\left(50.0 \mathrm{~m}^{2} / \mathrm{g}\right)$, mientras que el biocarbón obtenido de BC-GA mostró la menor $\left(2.0 \mathrm{~m}^{2} / \mathrm{g}\right)$. Por otro lado, las muestras obtenidas pueden clasificarse como materiales mesoporosos debido a que su tamaño de poro estuvo entre 2 y $50 \mathrm{~nm}$; esto indica que dichos materiales pueden usarse en procesos de absorción, aunque, se espera que el material proveniente de BC-AM sea el más adecuado para este tipo de aplicaciones. Los espectros FTIR no mostraron picos característicos de celulosa y hemicelulosa en ninguna de las muestras, lo cual se atribuye a su descomposición por las temperaturas alcanzadas en los procesos de gasificación. Adicionalmente, de acuerdo a los análisis SEM/EDX todas las muestras analizadas presentan estructuras de poros bien definidas y contienen minerales como $\mathrm{Na}, \mathrm{K}$ y Ca, lo cual sugiere que los biocarbones también podrían ser considerados para remediación de suelos.

Palabras clave: Acacia; Biocarbón; Especies forestales; Eucalyptus; Gmelina; Productos forestales; Propiedades fisicoquímicas.

\section{Resumo}

Neste estudo caracterizaram-se amostras de biocarvões obtidos como subproduto do processo de gasificação, em leito fixo a $700{ }^{\circ} \mathrm{C}$, das espécies Eucalyptus grandis (BC-EG), Acacia magnium (BC-AM) e Gmelina arborea (BC-GA). Suas características morfológicas e propriedades físico-químicas avaliaram-se usando fisisorção de nitrogênio pelo método de Brunauer-Emmet-Teller (BET), espectroscopia de dispersão de energia de raios $\mathrm{X}$ (EDS) e espectroscopia infravermelha com Transformada de Fourier (FTIR). Os biocarvões analisados apresentaram áreas superficiais na faixa de 2.0-50.0 $\mathrm{m}^{2} / \mathrm{g}$; o biocarvão originado da espécie BC-EG apresentou a maior área superficial $\left(50.0 \mathrm{~m}^{2} / \mathrm{g}\right)$, enquanto que o biocarvão obtido de BC-GA mostrou a menor $\left(2.0 \mathrm{~m}^{2} / \mathrm{g}\right)$. Por outro lado, as amostras obtidas podem classificar-se como materiais mesoporosos devido a que seu tamanho de poro esteve entre 2 e $50 \mathrm{~nm}$; isto indica que ditos materiais podem usar-se em processos de absorção, ainda que, espera-se que o material proveniente de BC-AM seja o mais adequado para este tipo de aplicações. Os espectros FTIR não mostraram picos característicos de celulose e hemicelulose em nenhuma das amostras, o que se atribui a sua decomposição pelas temperaturas alcançadas nos processos de gasificação. Adicionalmente, de acordo às análises $\mathrm{SEM} / \mathrm{EDX}$ todas as amostras analisadas apresentam estruturas de poros bem definidas e contêm minerais como $\mathrm{Na}$, $\mathrm{K}$ e Ca, o qual sugere que os biocarvões também poderiam ser considerados para remediação de solos.

Palavras chave: Acácia; Biocarvão; Espécies florestais; Eucalyptus; Gmelina; Produtos florestais; Propriedades físico-químicas. 


\section{INTRODUCTION}

Biochar is a low-value by-product obtained by the thermochemical conversion of biomass into heat, power, fuels and/or chemicals using an oxygen-limited environment [1-3]. The most common thermochemical processes are pyrolysis and gasification [2-4]. Biochar material can be used in agriculture, carbon sequestration and wastewater treatment [2]; this material is also effective in retaining nutrients and keeping them available to plants [5], thus by directly applying it into the soil, the conventional agricultural productivity and soil fertility may increase [6]. However, the specific application of biochar depends on its physicochemical properties, which could change depending on the process used for obtaining it, i.e., operating conditions and biomass feedstocks; therefore, the understanding of chemical and physical properties of the biochar is crucial to find its most suitable applications $[6,7]$.

Several characterization tests can be used to know the properties of biochar: the Brunauer-EmmetTeller (BET) nitrogen gas physisorption method traditionally studies the morphological characteristics and physical properties of biochar; while Scanning Electron Microscopy (SEM) and Energy Dispersive EDX (x-ray spectrometry) are commonly used to observe the morphology and the surface of the biochar [7-9]; and Fourier Transform Infrared Spectroscopy (FTIR) is frequently used to identify and qualitatively track changes in functional groups in biochar and soil samples [3].

Some authors have studied the effects of pyrolysis temperature on biochar properties. Jindo et al. [7] pyrolyzed rice husk, rice straw, and wood chips of apple tree and oak tree at temperatures between $400{ }^{\circ} \mathrm{C}$ and $800{ }^{\circ} \mathrm{C}$. They found by BET and FTIR that an increase in process temperatures results in higher surface area, more development of aromatic compounds and a decrease in aliphatic groups. Ghani et al. [10] evaluated the properties of biochar from waste rubber-wood-sawdust by pyrolysis between 450 ${ }^{\circ} \mathrm{C}$ and $850^{\circ} \mathrm{C}$, founding by BET analysis that the total surface is lower than $10 \mathrm{~m}^{2} / \mathrm{g}$ for lower temperatures and around $200 \mathrm{~m}^{2} / \mathrm{g}$ for higher temperatures. Kim et al. [11] evaluated the properties of biochar from pitch pine produced by fast pyrolysis at different temperatures $\left(300-500{ }^{\circ} \mathrm{C}\right)$; they obtained BET surface areas between 3.0 and $175 \mathrm{~m}^{2} / \mathrm{g}$ that increased with the pyrolysis temperature; from the FTIR spectra, they found that the O-H stretch peak $\left(3600-3200 \mathrm{~cm}^{-1}\right)$ decreases in the spectra for biochar. Azargohar et al. [12] produced biochar from pyrolysis of agricultural waste (wheat straw and flax straw) and forest residues (sawdust), at temperatures between $400^{\circ} \mathrm{C}$ and $550^{\circ} \mathrm{C}$; they found that increasing the pyrolysis temperatures resulted in ruptures on the biomass surfaces, caused by thermal cracking of their parent biomass; by FTIR analysis, they found that intensity of the peaks 3300$3400 \mathrm{~cm}^{-1}$ (-OH stretching), 2850-2950 $\mathrm{cm}^{-1}$ (-CH stretching), and $1470 \mathrm{~cm}^{-1}$ (deformation vibration from alkanes) decreased with an increase in the pyrolysis temperature, which can be due to the improvement of aromatic structure in biochar. Finally, Shaaban et al. [13] produced biochar from rubber wood sawdust at different temperatures and different holding times; the highest BET surface area $\left(6.0 \mathrm{~m}^{2} / \mathrm{g}\right)$ corresponded to the highest temperature $\left(700{ }^{\circ} \mathrm{C}\right)$ and the highest holding time $(3 \mathrm{~h})$.

Other authors have studied the properties of biochars obtained by different thermochemical processes, for instance, Brewer et al. [14] studied the characteristics of biochar obtained from fast pyrolysis, slow pyrolysis and gasification (in a bubbling fluidized bed reactor) of corn stover, switchgrass and wood. The biochar surface areas were between 3.0 and $62.0 \mathrm{~m}^{2} / \mathrm{g}$, and increased with the reaction residence time (fast pyrolysis < slow pyrolysis) and the temperature (pyrolysis < gasification). Luo et al. [15] analyzed the effect of operation conditions, including heating temperature (200-700 $\left.{ }^{\circ} \mathrm{C}\right)$, time (1-8 h), and atmosphere (air flow, air-limited and $\mathrm{N}_{2}$ ) on the physicochemical properties of biochar from pine sawdust, maize straw and sugarcane bagasse. They observed that the surface areas of the biochar significantly increased with temperature; in addition, operation under air condition or longer heating times (increased carbonization) tended to increase the micro-pore volumes and thus the surface areas of the biochar. Qian et al. [16] analyzed the physicochemical properties of biochar derived from fluidized-bed gasification of switchgrass forage sorghum; in this case, biochar surface areas did not exceed $10 \mathrm{~m}^{2} / \mathrm{g}$ and FTIR observations suggested that raw material has more aliphatic structure than gasified char.

In this study, the morphology and physical properties of biochar obtained as by-product from downdraft gasification of Eucalyptus grandis, Acacia magnium and Gmelina arborea are evaluated using BET, SEM, EDX and FTIR analyses. Such characterizations 
allowed predicting possible uses for these biochars. The selected forestry species present high silvicultural potential in Colombia [17], therefore, with this study, we expect to help promoting studies on thermal transformation of biomass, considering the potential in processes improvement when including biorefinery concepts regarding to low-value byproducts.

\section{Materials AND Methods}

\section{A. Wood gasification}

Biochar samples were obtained as by-product from downdraft gasification of Eucalyptus grandis (BCEG), Acacia magnium (BC-AM) and Gmelina arborea (BC-GA). The processes were carried out at atmospheric pressure, using biomass with similar shapes and sizes (chips with sizes between 4 and $10 \mathrm{~mm}$ ). The gasifying agent was air with a superficial velocity of $0.1 \mathrm{~m} / \mathrm{s}$ for all experiments. The complete description of the experimental process and the physicochemical characterization of biomass have been described in [17]. The maximum temperature reached in the gasification processes was approximately $700{ }^{\circ} \mathrm{C}$. Cold gas efficiencies between $25.8 \%$ and $30.9 \%$ were obtained. The lowest gas heating value obtained was between 2.5 and $3.0 \mathrm{MJ} /$ $\mathrm{Nm}^{3}$ with a mainly composition of $\mathrm{CO}, \mathrm{CO}_{2}, \mathrm{CH}_{4}, \mathrm{H}_{2}$ and $\mathrm{N}_{2}$, with average concentrations of $13 \%, 16 \%, 2$ $\%, 4 \%$, and $64 \mathrm{vol} \%$, respectively [17].

\section{B. Biochar characterization}

1) Surface area: The surface areas and pore size distribution of all materials were determined by the BET method from $\mathrm{N}_{2}$ isotherms measured at 75.2 K using a Quantachrome Autosorb Automated instrument. Each experiment used $100 \mathrm{mg}$ of solid biochar.

2) Scanning Electron Microscopy: The samples were analyzed by high-resolution scanning electron microscopy (HRSEM) in a JEOL 7600F electron microscope with an acceleration of $30 \mathrm{kV}$ and a theoretical resolution of $1 \mathrm{~nm}$. For this analysis, a solid sample homogeneously dispersed in pure ethanol was deposited on a $\mathrm{Cu}$ grid, previously covered with a thin layer of biochar. In addition, the analysis of elements was carried out by X-ray energy dispersive system spectroscopy (EDS), using a $\mathrm{Si}$ (Li) model INCA, Oxford.

3) Fourier Transform Infrared (FTIR): Infrared spectra of the biochar were recorded at room temperature and $2.0 \mathrm{~cm}^{-1}$ resolution on a IRAffiniti-1 Shimadzu spectrometer. Each sample for FTIR analysis was prepared by grinding and mixing $1 \mathrm{mg}$ of the biochar with $200 \mathrm{mg}$ of IR-grade $\mathrm{KBr}$, and then the sample was pressed into a pellet using a hydraulic press. The FTIR spectrum of the pellet was recorded over a wavenumber range of $650 \mathrm{~cm}^{-1}-4000 \mathrm{~cm}^{-1}$.

\section{RESULTS AND DISCUSSION}

\section{A. BET surface area and porosity}

The main surface characteristics of biochar are listed in Table 1. According to the average pore size, all samples can be classified as mesoporous materials because their pore sizes are between 2 and $50 \mathrm{~nm}$.

\section{TABLE 1}

SURFACE AREA AND POROSITIES OF THE BIOCHAR SAMPLES.

\begin{tabular}{|c|c|c|c|}
\hline Sample & BET Surface area $\left(\mathrm{m}^{2} / \mathrm{g}\right)$ & Average pore diameter $(\mathrm{nm})$ & Total pore volume $\left(\mathrm{cm}^{3} / \mathrm{g}\right)$ \\
\hline BC-AM & 50.0 & 4.25 & 0.052 \\
\hline BC-GA & 2.0 & 47.0 & 0.020 \\
\hline BC-EG & 30.0 & 5.3 & 0.040 \\
\hline
\end{tabular}

Biochar derived from Acacia magnium (BC-AM) had the highest surface area $\left(50.0 \mathrm{~m}^{2} / \mathrm{g}\right)$, while the biochar derived from Gmelina arborea (BC-GA) had the lowest surface area $\left(2.0 \mathrm{~m}^{2} / \mathrm{g}\right)$ (Table 1). Some authors have obtained surface areas in the same order of magnitude for biochar obtained from gasification processes. For instance, Qian et al. [16] obtained biochar with surface areas between 0.7 and $60 \mathrm{~m}^{2} / \mathrm{g}$ from switchgrass, sorghum straw and red cedar; and Brewer et al. [14] obtained biochar with surface 
areas between 24 and $31 \mathrm{~m}^{2} / \mathrm{g}$ from corn stover and switchgrass. Taking into account that the surface area of BC-AM is $96.4 \%$ greater than BC-GA, and 38.2 $\%$ higher than $\mathrm{BC}-\mathrm{EG}$, it is expected that the $\mathrm{BC}-\mathrm{AM}$ presents a greater adsorption capacity, considering that the adsorption capacity is expected to increase with the surface area. In future studies, the BC-AM biochar-sorption capability of selected contaminants, such as dyes in aqueous systems, will be evaluated.

\section{B. SEM-EDX}

Figure 1 shows the SEM micrographs of biochar obtained by gasification. In general, no sample revealed a definite shape, being BC-GA the most amorphous with poorly defined micrographs showing weak pores. This is consistent with its higher average pore diameter observed by BET analysis (Table 1). Table 2 shows the localized carbon and oxygen content of the samples determined by EDX-SEM analysis.

The SEM-EDX analysis showed that the BC-AM had the best development of pores (better-defined pores), with smaller pores than those developed by the other two biochars; while the BC-EG had larger developed pores, less defined and less uniform compared with the pores developed by BC-AM; and the BC-GA had uneven and weak pores that appear to be larger than the other samples (Fig. 1 and Table 2). These results are consistent with the BET results, in which BC-AM had greater surface area and smaller pore size than the other samples, while the BC-GA had the lowest surface area and a larger pore size (Table 1). The sample with the highest carbon content and the lowest oxygen content was the BC-GA. This result can be explained by physical properties of raw material (forest species) used as feedstock for the gasification process.

According to the literature, Gmelina arborea has the lowest bulk density among the studied species [17]. This promotes heat transfer during the gasification process because lower ratios of air/fuel are achieved (i.e., fewer amount of biomass in the same volume of reactor); thus, the process tends to combustion, increasing both temperature and reaction velocity. The highest carbonization degree is reflected in an increase in the carbon composition and a decrease in the oxygen composition of the biochar. A decrease in oxygen composition increases the surface hydrophobicity of the biochar [13].

\section{TABle 2}

Percentage of LOCALIZED CARBon, OXYGen AND SOME MINERALS CONTENT BY SEM-EDX ANALYSIS OF THE BIOCHAR (WT \%).

\begin{tabular}{|c|c|c|c|c|c|}
\hline Sample & $\mathrm{C}$ & $\mathrm{O}$ & $\mathrm{Na}$ & $\mathrm{K}$ & $\mathrm{Ca}$ \\
\hline BC-AM & 81.63 & 18.07 & 0.11 & 0.09 & 0.1 \\
\hline BC-GA & 88.36 & 9.12 & - & 1.33 & 0.89 \\
\hline BC-EG & 87.51 & 10.25 & - & 0.41 & 0.54 \\
\hline
\end{tabular}

A higher surface hydrophobicity could become a desirable attribute of a biochar for processes such as removing of contaminants from aqueous matrices; however, high surface areas are also desirable for such application [3], and according to Table 1, the BC-GA had the lowest BET surface area among the studied species. Therefore, considering BC-GA for sorption applications will probably require additional biochar activation processes to improve the BET surface area. On the other side, the presence in the biochar of minerals as $\mathrm{Na}, \mathrm{K}$ and $\mathrm{Ca}$ (Table 2) is considered an important characteristic for biochar applications such as soil amendment, since they are nutrient elements for plant growth [16, 18]. Among the tested samples, the highest mineral composition was found for the BC-GA; this result is consistent with the composition of $\mathrm{C}$ and $\mathrm{O}$, which results from the increase in gasification temperature, which increases volatilization of light compounds of raw material and reaction with the carbon during gasification, reducing the oxygen content of char and thus increasing the mineral contents [16]. Therefore, we can conclude that among the analyzed samples, BC-GA is the most suitable for soil remedial applications. 


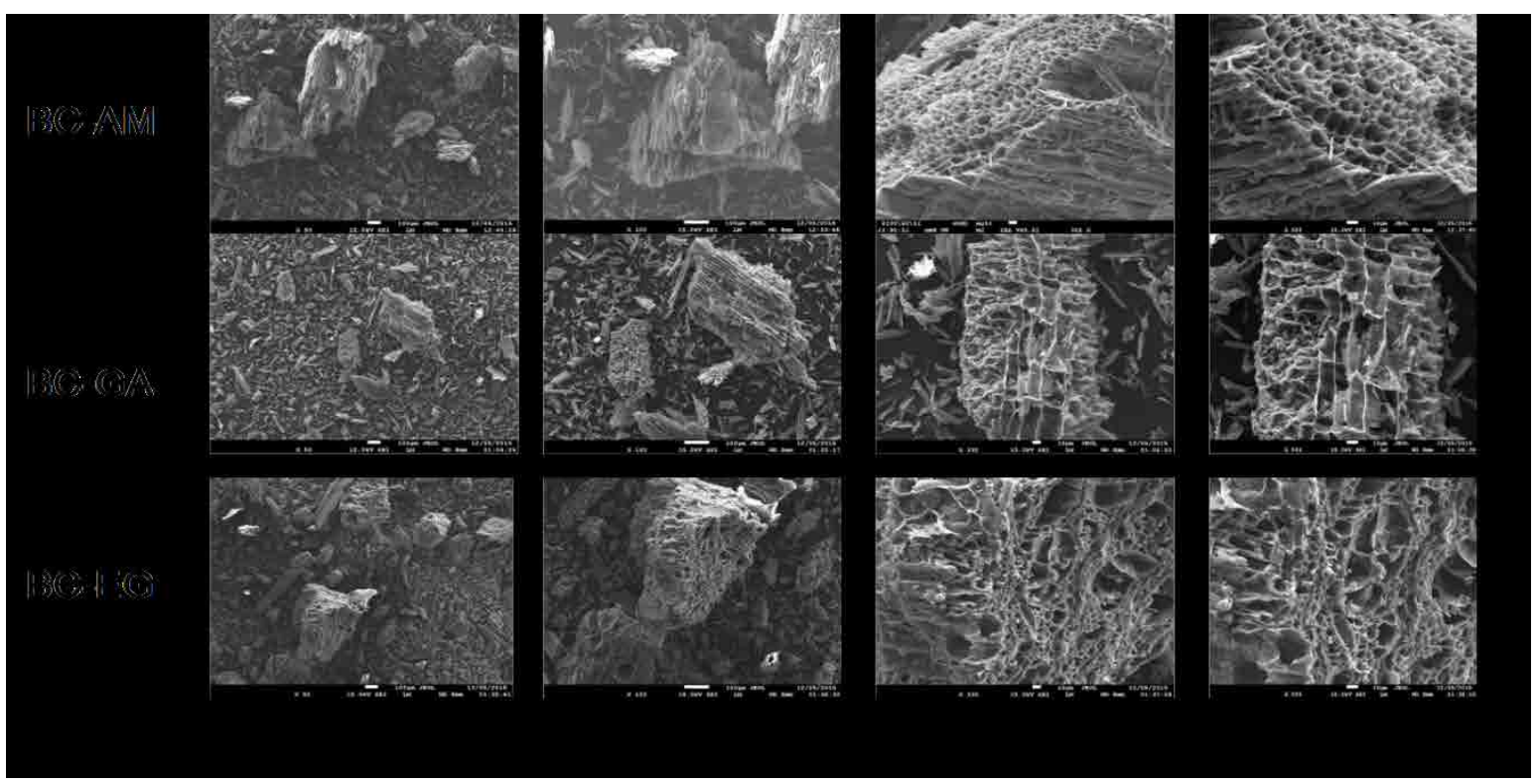

Fig. 1. SEM micrograph of biochar samples.

\section{FTIR Spectra}

Figure 2 shows the FTIR spectra in the $4000-2500 \mathrm{~cm}^{-1}$ and the $1800-1000 \mathrm{~cm}^{-1}$ range for the three biochars obtained under similar gasification conditions.
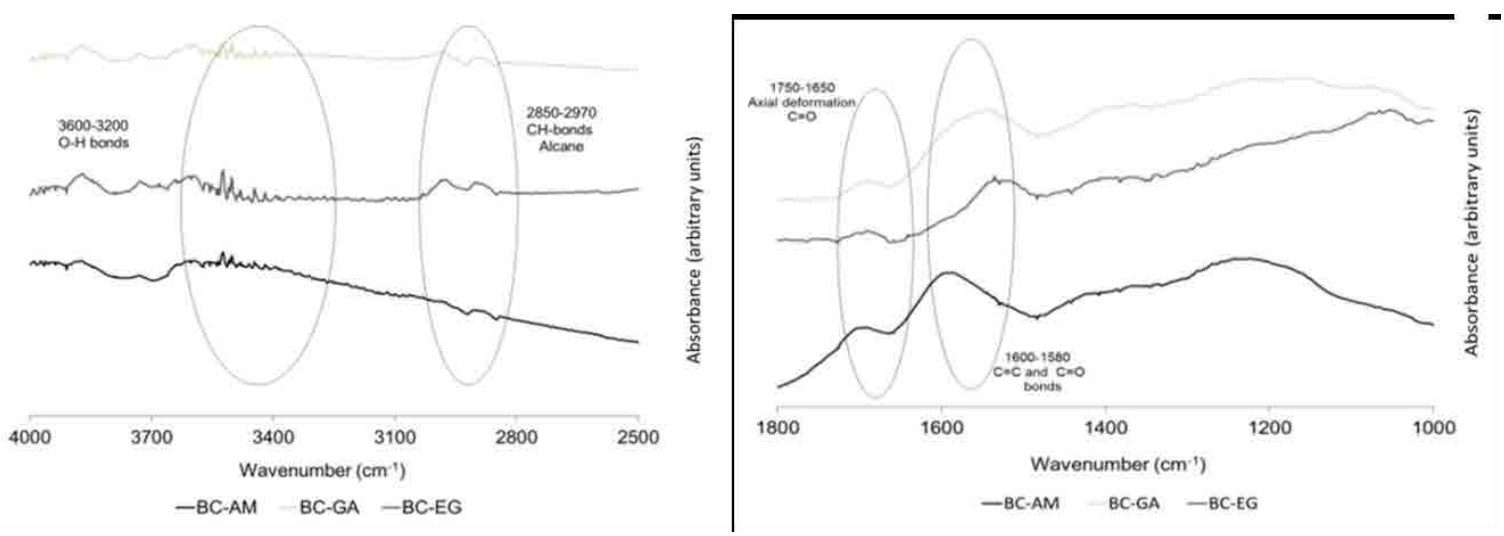

Fig. 2. FTIR spectra of biochar samples.

The FTIR spectra shows that the frequency range between $3600 \mathrm{~cm}^{-1}$ and $3200 \mathrm{~cm}^{-1}$ reveal the peaks corresponding to $\mathrm{OH}$ bonds (Fig. 2). The relative small size of these peaks is attributed to loss of moisture due to the high temperatures reached in the gasification process [11]. Clear peaks commonly attributed to hemicellulose and cellulose (i.e., $3200-3000 \mathrm{~cm}^{-1}$ for $\mathrm{OH}$ or $3100-3000 \mathrm{~cm}^{-1}$ for $\mathrm{CH}$ ) are absent in all the biochar samples, which lead us to conclude that the hemicellulose and cellulose present on the raw material (wood) degradated at the gasification temperatures
[19]. This is an expect result because the degradation of hemicellulose and cellulose generally take place at temperatures between $200-300{ }^{\circ} \mathrm{C}$ and $300-400{ }^{\circ} \mathrm{C}$, respectively [11]. Peaks between $1400 \mathrm{~cm}^{-1}$ and 900 $\mathrm{cm}^{-1}$ are generally attributed to lignin, mainly due to rings of type $\mathrm{C}=\mathrm{C}[19]$; these peaks are slightly more pronounced than those found for hemicellulose and cellulose, which can be attributed to the degradation of lignin at temperatures between $200{ }^{\circ} \mathrm{C}$ and $700{ }^{\circ} \mathrm{C}$ [12]. 
The peaks observed between $2850-2970 \mathrm{~cm}^{-1}$ are attributed to aliphatic functional groups ( $\mathrm{CH}$ bonds), and are poorly pronounced in the analyzed samples, because the degradation of aliphatic compounds occurs at high gasification temperatures, leading to the formation of aromatic compounds [12]. The peaks observed between $1750 \mathrm{~cm}^{-1}$ and $1650 \mathrm{~cm}^{-1}$ are attributed to the acid axial deformation $\mathrm{C}=\mathrm{O}$, primarily aldehydes and ketones formed by dissociation of cellulose and hemicellulose [12]. In the range of 1600$1580 \mathrm{~cm}^{-1}$, the observed bands are linked with aromatic $\mathrm{C}=\mathrm{C}$ and $\mathrm{C}=\mathrm{O}$, associated with ketones and quinones [19]. The FTIR analysis allowed us to conclude that the gasification process leads to the degradation of cellulose and hemicellulose, while some aromatics related with lignin remain in the biochar samples. According to [3], such characteristics could improve the biochar application as soil amendment.

From biorefinery concepts and aiming to improve low-value byproducts in the gasification process, the silvicultural potential of Colombia could focus on producing species such as Acacia magnium or Gmelina arborea to use them in the gasification process (for syngas or energy production), due to the potential use of the solid biochar by-product in different applications, i.e., absorption or soil amendment.

\section{Conclusions}

According to the characterization of biochar obtained by fixed-bed gasification of Eucalyptus grandis, Acacia magnium and Gmelina arborea, we can conclude that such biochar can be suitable for different specific applications. SEM micrographs revealed the best development of pores in BC-AM, while BET analysis showed lower average pore diameter $(4.25 \mathrm{~nm})$ and higher surface area $\left(50.0 \mathrm{~m}^{2} / \mathrm{g}\right)$ in BC-AM than in BC-EG or BC-GA; thus, the biochar obtained from Acacia magnium is expected to be the most suitable for absorption applications, even when adsorption capacity could be improved by additional activation processes. Based on the SEM-EDX analysis, we can conclude that due to the presence of minerals such as $\mathrm{K}, \mathrm{Na}$ and $\mathrm{Ca}$, biochars could be used as a soil amendment.

\section{ACKNOWLedgements}

The authors thank to GIMEL research group of the Universidad de Antioquia for collaboration with the biochar samples acquisition.

\section{Author's CONTRibution}

All authors have equally contributed to elaborate this manuscript.

\section{REFERENCES}

[1] J. Lehmann, and J. Stephen, Biochar for Environmental Management: Science, Technology and Implementation. $2^{\text {nd }}$ Ed. New York: Routledge, 2015.

[2] H. Kambo, and A. Dutta, "A comparative review of biochar and hydrochar in terms of production, physico-chemical properties and applications," Renew. Sustainable Energy Rev. vol. 45, pp. 359-378, 2015. DOI: http://doi.org/10.1016/j. rser.2015.01.050.

[3] Y. Sik, S. Uchimiya, S. Chang, and N. Bolan, Biochar: Production, Characterization and Applications. London: CRC Press, 2016.

[4] M. Inyang, and E. Dickenson, "The potential role of biochar in the removal of organic and microbial contaminants from potable and reuse water:Areview," Chemosphere, vol. 134, pp. 232-240, 2015. DOI: http://doi.org/10.1016/j.chemosphere.2015.03.072.

[5] S. Shenbagavalli, and S. Mahimairaja, "Production and characterization of biochar from different biological wastes," IJPAES, vol 2 (1), pp. 197-201, 2012.

[6] M. Sukiran, S. Loh, N. Abu, and Y. Choo, "Production and Characterization of Bio-Char from the Pyrolysis of Empty Fruit Bunches," Am. J. Appl. Sci., vol 8 (10), pp. 984-988, 2011. DOI: http://doi.org/10.3844/ ajassp.2011.984.988.

[7] K. Jindo, H. Mizumoto, Y. Sawada, M. SanchezMonedero, and T. Sonoki, "Physical and chemical characterization of biochars derived from different agricultural residues," Biogeosciences, vol. 11 (23), pp. 6613-662, 2014. DOI: http://doi.org/10.5194/bg11-6613-2014.

[8] L. Jechan, K. Ki-Hyun, and K. Eilhann, "Biochar as a Catalyst," Renew. Sustainable Energy Rev., vol. 77, pp. 70-79, 2017. DOI: http://doi.org/10.1016/j. rser.2017.04.002.

[9] Z. Bouraoui, M. Jeguirim, C. Guizani, L. Limousy, C. Dupont, and R. Gadiou, "Thermogravimetric study on the influence of structural, textural and chemical properties of biomass chars on $\mathrm{CO}_{2}$ gasification 
reactivity," Energy, vol. 88, pp. 703-710, 2015. DOI: http://doi.org/10.1016/j.energy.2015.05.100.

[10] W. Ghani, A. Mohd, G. da Silva, R. Bachmann, Y. Taufiq-Yap, U. Rashid, and A. Al-Muhtaseb, "Biochar production from waste rubber-woodsawdust and its potential use in $\mathrm{C}$ sequestration: Chemical and physical characterization," Ind. Crop Prod., vol. 44, pp. 18-24, 2013. DOI: http://doi. org/10.1016/j.indcrop.2012.10.017.

[11] K. Kim, J. Kim, T. Cho, and J. Choi, "Influence of pyrolysis temperature on physicochemical properties of biochar obtained from the fast pyrolysis of pitch pine (Pinus rigida)," Bioresource Technol., vol. 118, pp. 158-162, 2012. DOI: http://doi.org/10.1016/j. biortech.2012.04.094.

[12] R. Azargohar, S. Nanda, J. Kozinski, A. Dalai, and R. Sutarto, "Effects of temperature on the physicochemical characteristics of fast pyrolysis bio-chars derived from Canadian waste biomass", Fuel, vol. 125, pp. 90-100, 2014. DOI: http://doi. org/10.1016/j.fuel.2014.01.083.

[13] S. Shaaban, M. Se, M. Dimin, J. Juoi, M. Mohd, and N. Mitan, "Influence of heating temperature and holding time on biochars derived from rubber wood sawdust via slow pyrolysis", J. Anal. App.l Pyrol., vol 107, pp. 31-39, 2014. DOI: http://doi.org/10.1016/j. jaap.2014.01.021.

[14] C. Brewer, K. Schmidt-Rohr, J. Satrio, and R. Brown, "Characterization of biochar from fast pyrolysis and gasification systems," Environ. Prog. Sustain.
Energy, vol. 28 (3), pp. 386-396, 2009. DOI: http:// doi.org/10.1002/ep.10378.

[15] L. Luo, C. Xu, Z. Chen, and S. Zhang, "Properties of biomass-derived biochars: Combined effects of operating conditions and biomass types," Bioresource Technol., vol. 192, pp. 83-89, 2015. DOI: http://doi. org/10.1016/j.biortech.2015.05.054.

[16] K. Qian, A. Kumar, K. Patil, D. Bellmer, D. Wang, W. Yuan, and R. Huhnke, "Effects of biomass feedstocks and gasification conditions on the physiochemical properties of char," Energies, vol. 6 (8), pp. 39723986, 2013. DOI: http://doi.org/10.3390/en6083972.

[17] Y. Lenis, L. Osorio, and J. Pérez, "Fixed Bed Gasification of Wood Species with Potential as Energy Crops in Colombia: The Effect of the Physicochemical Properties," Energ. Source Part A, vol. 35 (17), pp.1608-1617, 2013. DOI: http://doi.org /10.1080/15567036.2012.704486.

[18] B. Rivka, D. Laird, M. Thompson, and M. Lawrinenko, "Characterization and quantification of biochar alkalinity," Chemosphere, vol. 167, pp. 367-373, 2017. DOI: http://doi.org/10.1016/j. chemosphere.2016.09.151.

[19] M. Jouiad, N. Al-Nofeli, N. Khalifa, F. Benyettou, and L. Yousef, "Characteristics of slow pyrolysis biochars produced from rhodes grass and fronds of edible date palm," J. Anal. Appl. Pyrol., vol. 111, pp. 183-190, 2015. DOI: http://doi.org/10.1016/j. jaap.2014.10.024. 